Pak. j. sci. ind. res. Ser. B: biol. sci. 2019 62B(3) 195-198

\title{
Nematodes Associated with Two Species of Mentha (Lamiaceae) in Balochistan, Pakistan
}

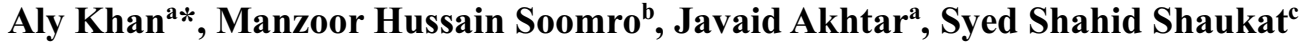 \\ ${ }^{a}$ Crop Diseases Research Institute, PARC, University of Karachi, Karachi-75270, Pakistan \\ ${ }^{b}$ Science Foundation (ECOSF), 1 Constitution Avenue, G-5/2, Islamabad, Pakistan \\ 'Institute of Environmental Studies, University of Karachi, Karachi-75270, Pakistan
}

(received April 18, 2017; revised November 15, 2017; accepted December 5, 2017)

\begin{abstract}
Nematodes associated with Mentha spicata L. and Mentha longifolia L. were investigated in Balochistan in various localities so as to assess the variation in density of different nematode species found in the rhizosphere. Ten species of nematodes were found associated with Mentha spicata while four species were found in the rhizosphere of M. longifolia. Significant differences in nematode density were recorded ( $\mathrm{p}$ at the most $\mathrm{p}<0.01$ ). The dominant nematodes associated with Mentha spicata were Pratylenchus projectus and Merlinius khuzdarensis while those associated with Menthe longifolia were Xiphinema americanum and Pratylenchus thornei.
\end{abstract}

Keywords: mint, Balochistan, plant parasitic nematodes

\section{Introduction}

Mint (Mentha) is a genus of plants in the family Lamiaceae. Almost 13-18 species exist and exact distinction between the existing species is unclear (Bunsawat et al., 2004). It is sub-cosmopolitan distributed across Europe, Australia, Africa, Asia and North America. Although the mint species are widely distributed and can be found in many environments, majority grow better in moist soils and wet environments such as near pools of water, lakes, rivers and cool moist localities in partial shade (Bradley, 1992).

It is cultivated for its aroma, culinary use and medicinal properties. The common diseases associated with mint are leaf blight, Fusarium wilt, and stolon rot besides plant parasitic nematodes. Several nematode species have been found to be associated or parasitizing Mentha spp. in different countries. Khanzada et al. (2012) studied thirteen mint species for the presence of nematodes associated with their rhizosphere. Tylenchorhynchus spp. were found to be associated with highest number of mint species which were seven while Trichodorus was found associated with only one mint species. The highest population recorded was of Helicotylenchus from six species. There were six genera of plant nematodes found associated with Mentha, namely Helicotylenchus sp., Hoplolamous sp., Longidorus sp., Tylenchorhynchus sp., Trichodorus sp. and Xiphenima sp. (Vovlas et al., 2006) recorded cystoids nematode Meloidoderita

*Author for correspondence; E-mail: aly.khan@hotmail.com kirjanovae associated with Mentha aquotica from Southern Italy. Hafez et al. (2010) reported following nematodes from Mentha piperita namely Helicotylenchus digonicus, Mesacriconema ornatum, Pratylenchus projectus, P. tenuicaudatus, $P$. coffeae, P. penetrans, $P$. thornei and Tylenchorhynchus clarus while those associated with Mentha spicata were Aphenenchoides fragariae, Pratylenchus lepidus, P. projectus, P. coffeae, $P$. neglectus and $P$. penetrans from Idaho, USA.

Sultan et al. (2013) conducted intensive survey of plant nematodes associated with Mentha arvensis. The results indicated that 19 out of 24 samples in Uttar Pradesh, India had plant nematodes including Hoplolaimus spp.; Meloidogyne incognita, Helicotylenchus spp. and Tylenchorhynchus spp. In similar studies Haseeb and Pandey (1989) reported Meloidogyne javanica and Meloidogyne incognita associated with Japanese mint (Mentha arvensis) in Uttar Pradesh, India. The severity of infection of M. incognita was more prevalent although it varied from variety to variety.

Plant nematode reduces the yield of Mentha spp. causing economic losses. Diverse climatic conditions in Balochistan along with different cropping sequence are considered to be highly conducive for the multiplication of plant nematodes. Information concerning the distribution and occurrence of nematodes in Balochistan is of significant importance to assess their potential to cause economic damage for Mentha crop. 
In the present investigation nematodes associated with two mint species namely Mentha spicata L. and Mentha longifolia L. are being reported from different localities of Balochistan.

\section{Materials and Methods}

In November 2014 rhizosphere soil from two mint species namely Mentha spicata L. and M. longifolia L., showing either yellowing, stunted patches or foliar burning system were collected from different localities of Khuzdar and Kalat districts, Balochistan. M. spicata samples were collected from Baghbana, Khuzdar, Rahimabad and Wadh while $M$. longifolia were collected from Alizai, Kalat, Kork and Mengalabad.

A total of six samples were taken from each locality from a depth of $0-10 \mathrm{~cm}$. Information on most of the sites was not available but the most common sequence pattern was onion and wheat. Soil type in the region was usually loamy sand ( $76 \%$ sand, $15 \%$ silt, $9 \%$ clay) and $\mathrm{pH}$ for the field soil ranged from 7.7 to 7.9 . Samples collected were placed in labeled plastic bags, sealed and brought back to the Nematology Laboratory, PARC where they were stored at $5{ }^{\circ} \mathrm{C}$ until processed for nematode extraction (Mckenry and Roberts, 1985). Collected nematode population in petri plates were identified and counted under stereo-binocular microscope. The nematodes were counted in a glass chamber. Identification of nematode species was based on the morphology and measurements (Choi, 2001, Siddiqi, 2000).

One-way analysis of variance (ANOVA) for each species was performed with localities as the factor. Fisher's least significant difference (LSD) was calculated at $\mathrm{p}$ $=0.05$. In addition, standard error $(\mathrm{SE})$ is given against means (Zar, 1996).

\section{Results and Discussion}

The nematodes associated with mint (Mentha spicata) were Filenchus sp.; Andrássy, 1954; Helicotylenchus digonicus Perry, 1959; H. inducus Siddiqi, 1963; Longidorus sp., (Nicol, 1922) Meyl, 1961; Merlinius khuzdarensis Handoo et al., 2007; Pratylenchus projectus Jenkins, 1956; P. penetrans (Cobb, 1917) Filipjev and Stekhoven, 1941; P. thornei Sher and Allen, 1953; Tylenchorhynchus sp., Cobb, 1913 and Xiphinema basiri Siddiqi, 1959. M. spicata growingin Rahimabad, Balochistan were infected with ten different nematode species (Fig. 1).
While the nematodes associated with mint species (M. longifolia) were Hoplolaimus sp., von Daday, 1905, Pratylenchus penetrans; P. thornei and Xiphinema americanum Cobb, 1913. M. Longifolia growing in Kork were infected with four different nematodes belonging to three genera (Fig. 2).

The results of Mentha spicata for differences in density among four localities are given in Table 1. All ten species showed highly significant differences among

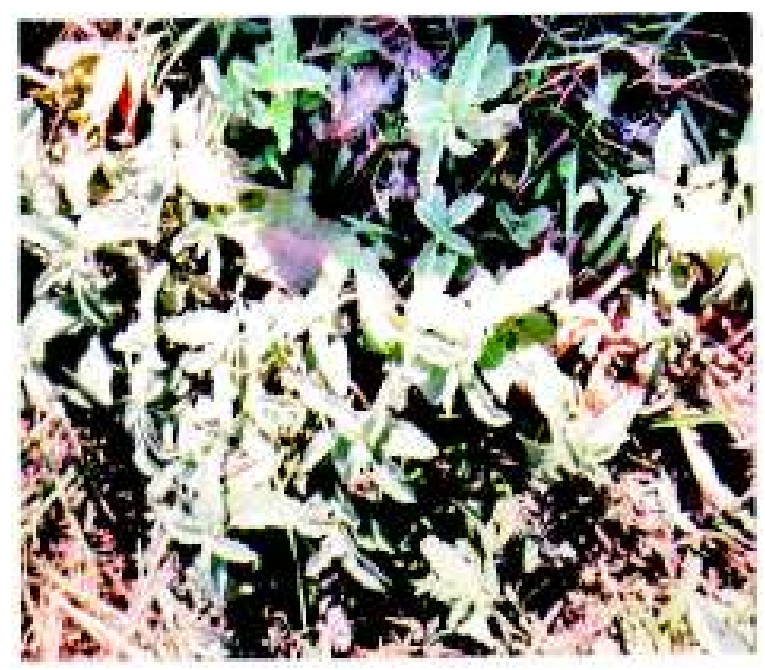

Fig. 1. Mentha spicata L. growing in Rahimabad, Balochistan infested with ten different nematode species.

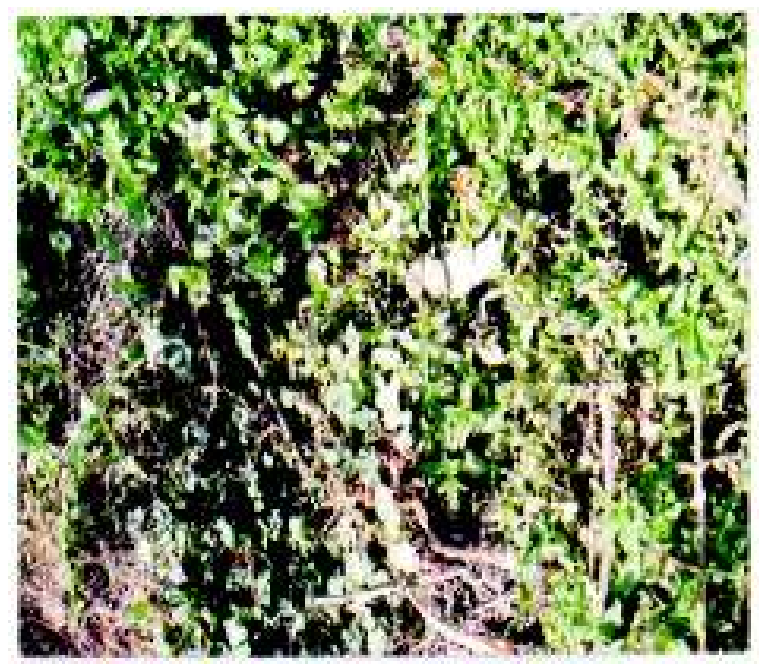

Fig. 2. Mentha longifolia L. growing in Kork, Balochistan infected with four nematode species. 
Table 1. Results of ANOVA of Mentha spicata for differences in density of nematodes of 4 localities

\begin{tabular}{|c|c|c|c|c|c|c|}
\hline \multirow[t]{2}{*}{ Nematodes } & \multicolumn{4}{|c|}{ Localities } & \multirow[t]{2}{*}{$\mathrm{F}$} & \multirow{2}{*}{$\begin{array}{l}\text { LSD } \\
0.05\end{array}$} \\
\hline & 1 & 2 & 3 & 4 & & \\
\hline Filenchus sp. & $163 \pm 32$ & $28 \pm 6.13$ & $415 \pm 106$ & $37 \pm 11.97$ & $10.56 \mathrm{p}<0.001$ & 116.02 \\
\hline Helicotylenchus digonicus & $135.66 \pm 55.59$ & 0 & 0 & 0 & $21.18 \mathrm{p}<0.001$ & 42.75 \\
\hline H. indicus & $89.66 \pm 13.11$ & $26.5 \pm 6.32$ & $16.5 \pm 1.65$ & $129.5 \pm 1.45$ & $56.13 \mathrm{p}<0.001$ & 21.68 \\
\hline Longidorus sp. & $358.83 \pm 75$ & 0 & $10 \pm 1.46$ & $18 \pm 2.51$ & $1970.2 \mathrm{p}<0.001$ & 11.64 \\
\hline Merlinius khuzdarensis & $362.5 \pm 8.61$ & 0 & $10 \pm 1.39$ & $18.66 \pm 1.67$ & $1599.13 \mathrm{p}<0.001$ & 13.06 \\
\hline Paratylenchus projectus & $439.3 \pm 28.6$ & $14.33 \pm 1.35$ & $36.16 \pm 10.24$ & $230.5 \pm 57.21$ & $37.67 \mathrm{p}<0.001$ & 95.29 \\
\hline P. penetrans & 0 & $43.16 \pm 2.62$ & $55.5 \pm 4.34$ & $37.83 \pm 3.93$ & $55.33 \mathrm{p}<0.001$ & 9.48 \\
\hline P. thornei & 0 & 0 & $107 \pm 0.89$ & $101 \pm 9.22$ & $13.78 \mathrm{p}<0.001$ & 50.3 \\
\hline Tylenchorhynchus sp. & 0 & 0 & $61.83 \pm 0.90$ & $49.16 \pm 12.41$ & $27.23 \mathrm{p}<0.001$ & 18.54 \\
\hline Xiphinema basiri & $160 \pm 0.57$ & 0 & 0 & 0 & $768 \mathrm{p}<0.001$ & 0.8515 \\
\hline
\end{tabular}

*Localities 1 = Baghbana; 2 = Khuzdar; 3 = Rahimabad; 4 = Wadh.

Table 2. Results of ANOVA of Mentha longifolia for differences in density of nematodes of 4 localities

\begin{tabular}{lllllll}
\hline \hline Nematodes & & \multicolumn{2}{c}{ Localities } & F & LSD \\
\cline { 2 - 5 } & 1 & 2 & 3 & 4 & 0.05 \\
\hline Hoplolaimus sp. & 0 & $42.16 \pm 0.80$ & $147.16 \pm 11.80$ & $8.16 \pm 0.47$ & $131.95 \mathrm{p}<0.001$ & 17.38 \\
Pratylenchus penetrans & 0 & $14.16 \pm 1.70$ & $9.83 \pm 2.12$ & $15.5 \pm 2.58$ & $13.50 \mathrm{p}<0.001$ & 5.63 \\
P. thornei & 0 & 0 & $203.3 \pm 55.47$ & $52.8 \pm 13.71$ & $11.80 \mathrm{p}<0.001$ & 82.53 \\
Xiphinema americanum & $366.66 \pm 134.6$ & $47.33 \pm 10.97$ & $178.66 \pm 3.28$ & 0 & $5.944 \mathrm{p}<0.01$ & 198.56 \\
\hline
\end{tabular}

*1 = Alizai; 2 = Kalat; 3 = Kork; 4 = Mengalabad.

localities $(\mathrm{p}<0.001)$. The results of Mentha longifolia for density variation in the selected localities are presented in Table 2. Three species including Hoplolaimus sp. P. penetrans and $P$. thornei showed significant differences $(\mathrm{p}<0.001)$ between localities while $X$. americanum showed significant difference at $\mathrm{p}<0.01$.

Some reports suggested that yield losses by different plant parasitic nematodes to mint crop can aggravate if Verticillium wilt disease is present in the fields, as the nematode feeding sites may become entry for fungi in the roots (Weller et al., 1998). Rhoades (1983) suggested that root weight was significantly reduced by all three nematodes Belonolaimus longicaudatus, Dolichodorus heterocephalus and Pratylenchus scribneri of mint in a pot trial. Rakesh et al. (2010) suggested that rootknot nematodes (Meloidogyne incognita and M. javanica) and root lesion nematode (Pratylenchus thornei) affect cultivation of menthal mint in Indo-Gangetic plains.

Johnson and Santo (2001) reported that nematode pathogen cause disease complex between Pratylenchus penetrans and Verticillium dahlia on mint.
Bergeson and Green (1979) studied association of nematode with 3 cultivars of $M$. piperita, M. spicata cv. Native and M. cardiaca cv. Scotch in Indiana, USA. Three most frequent nematodes were Pratylenchus penetrans, Longidorus sp. and Xiphinema americanum. They further tested susceptibility of three M. piperita cultivars to $P$. penetrans in a pot experiment. In another pot experiment, an inoculum of 5000 nematodes/pot resulted in reduction in root weight of cv. Black Mitcham, Murray Mitcham and Todd's Mitcham by 48, 59 and $41 \%$.

This study on plant parasitic nematodes associated with Menth species shall provide important information to extension staffs so that they could create awareness among the growers.

Conflict of Interest. The authors declare no conflict of interest.

\section{References}

Bergson, G.B., Green, Jr. R.J. 1979. Damage to cultivars of peppermint, Mentha piperita by lesion nematode, 
Pratylenchus penetrans of Indiana. Plant Disease Report, 63: 91-94.

Bradley, F. 1992. Rodale's All New Encyclopedia of Organic Gardening. 390 pp., Rodale Press, Emmaus, Pennsylvania, USA.

Bunsawat, J., Elliot, N.E., Hertweck, K.L., Sproles, E., Alice, L.A. 2004. Phylogenitics of Mentha (Lamiaceae): Evidence from Chloroplast DNA sequences. Systematic Botany, 29: 959-964.

Choi, Y. 2001. Nematoda (Tylenchida, Aphelenchida). Economic Insects of Korea 20. 392 pp., Ins. Korean Supplement, 27, Korea.

Hafez, S.L., Sundararaj, P., Handoo, Z.A., Siddiqi, M.R. 2010. Occurrence and distribution of nematodes in Idaho crops. International Journal of Nematology, 20: 91-98.

Haseeb, A., Pandey, R. 1989. Observations on Meloidogyne species affecting Japanese mint-new disease record. Nematropica, 19: 93-97.

Johnson, D.A., Santo, G.S. 2001. Development of wilt in mint in response to infection by two pathotyped of Verticillium dahlie and co-infection by Pratylenchus penetrans. Plant Disease, 85: 1189-1192.

Khanzada, S.A., Naemullah, M., Munir, A., Iftikhar, S., Masood, S. 2012. Plant parasitic nematodes associated with different mentha species. Pakistan Journal of Nematology, 30: 21-26.

McKenry, M.V., Roberts, P.A. 1985. Phytonematology Study Guide. M. V. McKenry and P. A. Roberts (eds.), 56 pp., Publication 4045, Co-operative Extension University of California. Division of Agriculture and Natural Resources, Oakland, USA.

Rakesh, P., Mishra, A.K., Tiwari, S., Kalra, A., Singh, H.N. 2010. Phytonematodes: A severe menace for successful cultivation of menthol mint in IndoGangetic plains. Medicinal Plants, 2: 175-180.

Rhoades, H.I. 1983. Effect of Belonolaimus longicaudatus, Dolicodorus heterocephalus and Pratylenchus scribneri on growth of spearmint Mentha spicata, in Florida. Nematropica, 13: 145-151.

Siddiqi, M. 2000. Tylenchida. Parasites of Plants and Insects. 848 pp., $2^{\text {nd }}$ edition, CABI Publishing, UK.

Sultan, S.A., Sehgal, M., Arora, S., Singh, A., Srivastava, D.S., Yadav, A.S., Saurabh, Bisen, M.K., Singh, S.K. 2013. Plant parasitic nematodes associated with menthe field of Sitapur, UP, India. Current Nematology, 24: 5-8.

Weller, S., Green, R. Jr., Janssen, C., Whitford, F. 1998. Mint Production and Pest Management in Indiana. 14 pp., Purdue University Cooperative Extension Service, West Lafayette, IN, USA.

Vovlas, N., Landa, B.B., Liebanas, G., Handoo, Z.A., Subbotin, S.A., Castillo, P. 2006. Characterization of the cystoid nematode Meloidoderita kirjanovae (Nematoda: Sphaeronematidae) from Southern Italy. Journal of Nematology, 38: 376-382.

Zar, J.H. 1996. Biostatistical Analysis. 662 pp., $3^{\text {rd }}$ edition. Prentice Hall, New Jersey, USA. 